\title{
Estimating a Stock-Flow Model for the Swiss Housing Market ${ }^{a}$
}

\author{
Elizabeth STEINER ${ }^{\mathrm{b}}$
}

JEL-Classification: C32, E22, E32, R21, R31

Keywords: housing demand, housing supply, residential investment, market disequilibrium, housing prices

\section{Introduction}

Strong fluctuation in housing prices is a widespread phenomenon which has been repeatedly observed in numerous countries. An overheating of the housing market can finish painfully, not only for market participants themselves but also for the institutions financing housing projects. Furthermore, there is a considerable risk that a housing market crisis will spread to other sectors and end in a broad-based recession.

In contrast to other countries, Switzerland has, since the 1990s, experienced no alarming rise in housing prices - apart from some local overheating. In the late eighties, however, housing prices in Switzerland soared. The unforeseen rapid rise in prices was followed by a sudden drop. It took a number of years for the market to stabilize, and real housing prices only started to edge up again in 2001. In 2007 real housing prices were still well below their peak level of 1989 . The massive drop in prices at the beginning of the nineties had harmful consequences for many parts of the economy: Growth in residential construction turned negative. The financial situation of households was massively weakened. The balance sheets of many firms deteriorated sharply. Banks found themselves with an elevated volume of bad credits, and it took years for the financial sector to recover from the large losses. Given the destabilizing impact of large housing price volatility, it is useful to know more about the forces influencing the housing market.

a The author would like to thank Katrin Assenmacher, Sarah Lein, Angelo Ranaldo, Barbara Rudolf, Jonas Stulz, Caroline Schmidt, Peter Tillman, Attilio Zanetti, Mathias Zurinden and an anonymous referee for their valuable contribution to this paper.

b Swiss National Bank (SNB), Börsenstrasse 15, PO Box, 8022 Zurich, Switzerland, Email: elizabeth.steiner@snb.ch. 
The goal of this paper is to analyze the determinants of the Swiss housing market. With the estimated model it is possible to quantify the gap between the existing supply and the desired level of housing stock and to measure the impact of these housing market imbalances on prices. The model makes it possible to determine whether actual housing market developments are in line with macroeconomic fundamentals or not. Furthermore, as the model is kept simple, it is possible to simulate different scenarios in order to forecast potential developments on the housing market.

Special features of this paper are the use of Swiss residential capital stock data in real CHF calculated with the perpetual inventory method as proposed by the Swiss Federal Statistical Office (FSO) and the long estimation sample, which starts in 1975 and thus covers several business cycles.

This paper is structured as follows: Section 2 explains the stock-flow framework, section 3 describes the estimated model, section 4 shows empirical results and section 5 concludes. A data description is provided in the appendix.

\section{The Stock-Flow Framework}

The dynamics of durable goods, such as housing, are typically estimated with a stock-flow model. A stock-flow model makes a distinction between the stock of housing, which is rigid in the short run, and the flow of residential investment, which can react quicker to changes in macroeconomic conditions. The housing stock and the flow of residential investment are linked together through two channels.

Firstly, the residential capital stock is the accumulation of residential investment over time. The rate of expansion of the stock depends on the rate of expansion of gross residential investment and the rate of depreciation, which is often assumed to be constant over time. The residential capital stock develops smoothly and does not react quickly to shocks. The sluggish adjustment process is due to the fact that the rate of depreciation of residential capital stock is low. Therefore, the ratio of the flow to the stock is also low. In Switzerland, net residential investment (residential investment minus depreciation) accounts only for about $2 \%$ of the housing stock, making quick variations in the level of the residential capital stock practically impossible. The sluggish adjustment of the stock may

1 For details on the Swiss housing stock and residential investment, see Data appendix 6.2 and 6.3 . 
be additionally delayed by the fact that the flow of residential investment also reacts relatively slowly to shocks. This is because of the lengthy "time to build" and also because residential investment is lumpy and investment decisions often costly to reverse.

Secondly, the residential capital stock and the flow of residential investment are linked together through housing prices. Housing prices, which are determined by the level of the housing stock, have a strong influence on the flow of new residential investment.

An important feature of the housing market is the heterogeneous adjustment speed of its determinants: While the stock reacts slowly, housing prices and investment respond quicker to shocks. The different adjustment speed of housing market variables is captured by introducing a disequilibrium approach to the model.

This paper is based on housing market research done abroad using the stockflow approach. DiPasquale and Wheaton (1994) made a seminal contribution to housing market economics with their paper published in 1994. They analyzed the US housing market within a stock-flow framework and find strong evidence that it takes several years for the housing market to clear. They therefore extend the traditional stock-flow model by allowing prices to converge to equilibrium over several periods. They propose an equation for a market clearing price determined by demand variables and the actual stock. DiPasquale and Wheaton estimate a separate equation for residential investment in which construction is dependent on housing prices, the level of the existing stock and an array of cost shifters.

McCarthy and Peach (2002) implement the DiPasquale and Wheaton stockflow model in an error-correction framework. Using US data, they estimate an equilibrium price of housing which is determined by the existing housing stock and demand-shifting variables. This is a hypothetical, unobserved, market clearing price that would clear the existing residential stock in the absence of market imperfections. The residuals of this equation are used to estimate short-run variations in housing prices. Furthermore, they estimate an equilibrium price that would be consistent with the long-run equilibrium level of residential investment. Differences between this equilibrium price and the actual price are then used to estimate residential investment dynamics.

2 "Time to build" includes, besides the actual construction period, also the time needed for architectural planning as well as the time needed to acquire a dwelling approval. According to analysis done by Peters and WAPF (2007), the total "time to build" in Switzerland is on average 18 months. 
Alternative empirical models which describe the housing market from a stockflow perspective have been provided by Topel and Rosen, Riddle, and Demers. Topel and Rosen (1988) investigate thoroughly the dynamics of residential investment in the US and conclude that residential investment responds to changes in housing prices but that the long-run supply elasticity is clearly higher than in the short run. RidDle (2004) uses a disequilibrium housing market model based on US data. She estimates an equilibrium level of the stock using demand-shifting variables. The residuals from this equation are used to explain the short-run change in prices. She then estimates an equilibrium level of the stock using housing prices and cost-shifting variables. The residuals from this second equation are then used to explain net residential investment. Demers (2005) estimates long-run equations for residential investment and housing prices in Canada as well as equations for the short-run dynamics of these variables in an equilibrium correction model setting.

To our knowledge this is the first study using a stock-flow framework for Switzerland. In recent years, however, some very interesting work has been published on the Swiss housing market, for example by Bourassa, Hoesli and Scognamiglio (2009), Borowiecki (2009) and Нотt (2009).

The model presented in this paper is derived from the work of McCarthy and Peach. Their basic idea that housing stock imbalances lead to price adjustment in the next period and that investment imbalances influence investment growth in the next period has been maintained. However, in contrast to the model described by McCarthy and Peach, the model proposed in this paper does not aim to estimate equilibrium prices for the housing stock and for residential investment. The equations have been rearranged in order to estimate the size of the housing market imbalance and the dynamics of housing prices and residential investment. This makes the pass-through of a housing market shock more explicit and the output of the model easier to interpret.

\section{A Model of the Housing Market}

In this section we present an empirical approach to model housing prices and residential investment dynamics in the framework of a stock-flow model. The residential capital stock and residential investment are linked together through the following capital accumulation identity:

$$
S_{t}=I_{t}+(1-d) S_{t-1}
$$


Equation (1) states that the residential capital stock in period $t, S_{t}$, is the sum of residential investment made in period $t, I_{t}$, and the level of the residential capital stock in $t-1$ net of depreciation, $(1-d) S_{t-1}$. In our model, $S_{t}$ stands for the supply of existing housing stock.

In the long run, the supply of existing housing stock should equate demand (lower case letters denote variables in logarithms):

$$
s_{t}=\alpha_{1}-\alpha_{2} p_{t}+\alpha_{3}^{\prime} U_{t}+\varepsilon_{t}^{s}
$$

The long-run demand, $\alpha_{1}-\alpha_{2} p_{t}+\alpha_{3}^{\prime} U_{t}$, is determined by housing prices and its position depends on a set of demand shifting variables, summarized in vector $U_{t}$. These could be population, income or wealth. $\varepsilon_{t}^{s}$ tracks the short-run deviation between the supply of existing housing stock and its desired level, i.e. the level of housing market imbalance.

As the residential capital stock can only adjust slowly to shocks, a simultaneous clearing of the housing market can only be achieved if prices react fully in the same period (i.e. the actual housing price equals the market clearing price and $\left.\varepsilon_{t}^{s}=0\right)$. As shown in several studies done for the US market, this is often not the case. ${ }^{3}$ In general the housing market takes several periods to clear.

When $\varepsilon_{t}^{s}$ is negative, the desired level of housing stock is higher than the existing supply. The housing market is in a situation of excess demand and real housing prices will tend to rise. When $\varepsilon_{t}^{s}$ is positive, the housing market is characterized by excess supply and housing prices will normally fall. Housing prices respond to housing market imbalances as follows:

$$
\Delta p_{t}=\varphi_{1}+\varphi_{2} \varepsilon_{t-1}^{s}+\varphi_{3}^{\prime} W_{t}+\mu_{t}
$$

Equation (3) allows housing prices to react to $\varepsilon_{t}^{s}$ over several periods: $\varphi_{2}$ indicates the speed of price adjustment and is expected be negative. Additionally, changes in housing prices are expected to be a function of various factors, summarized in vector $W_{t}$.

Housing prices, which are determined by the demand and supply of housing stock, influence the flow of residential investment. Higher housing prices provide an incentive to build new houses and boost residential investment. The long-run residential investment equation can be expressed as: 


$$
i_{t}=\beta_{1}+\beta_{2} p_{t}+\beta_{3}^{\prime} Z_{t}+\varepsilon_{t}^{i}
$$

Besides, residential investment depends on a vector of cost-shifting variables, $Z_{t}$, which typically include construction costs or capital costs. $\varepsilon_{t}^{i}$ tracks the level of over- or under-investment which cannot be explained by the variables in equation (4). The dynamics of residential investment expressed in first differences are described by the following equation:

$$
\Delta i_{t}=\gamma_{1}+\gamma_{2} \varepsilon_{t-1}^{i}+\gamma_{3}^{\prime} V_{t}+\zeta_{t}
$$

Equation (5) allows a fraction of $\varepsilon_{t}^{i}$ to be corrected in the following period. The speed of adjustment is given by the coefficient $\gamma_{2}$, which is expected to lie between 0 and -1 . The vector $V_{t}$ comprises various factors which influence changes in residential investment.

\section{Estimation Results}

All estimates shown in this paper are based on annual data from 1975 to 2007. Data sources and further details on data can be found in the appendix.

\subsection{The Estimated Long-Run Level of Residential Capital Stock}

As proposed in equation (2), the long-run demand for residential housing stock is determined by housing prices ${ }^{4}$ and a set of demand- shifting variables. In our estimations, the variables included in vector $U_{t}$ are the logarithms of real GDP, $g d p_{t}$, as a broad measure of income and the logarithms of the real wages index ${ }^{5}$, $w_{t}$, as a measure of labor market conditions The dependent variable, is $s_{t}$, the logarithms of the housing stock. The variables in the equation are all I(1).

$$
s_{t}=\alpha_{1}-\alpha_{2} p_{t}+\alpha_{3} g d p_{t}+\alpha_{4} w_{t}+\varepsilon_{t}^{s}
$$

Parameter estimates are shown in Table 1. The coefficients have the expected sign and are statistically significant. According to the augmented Dickey-Fuller Unit

4 Real housing prices are measured by the supply price index published by Wüest \& Partner AG, deflated with the GDP deflator; see Data appendix 6.4.

5 As the Swiss real wage index and Swiss real GDP are not correlated there is no risk of inducing multicollinearity into the empirical model; see Data appendix 6.5. 
Root Test, the null hypothesis of $\varepsilon_{t}^{i}$ having a unit root is rejected at the $5 \%$ level. ${ }^{6}$ The residuals of equation (6), i.e. the stock imbalance, are shown in Figure 2.

Table 1: Two-Stage Least Squares Parameter Estimates of Equation (6), 1975-2007

\begin{tabular}{lcc}
\hline Independent variable & \multicolumn{2}{c}{ Estimate } \\
\hline$C$ & $-7.96^{* * *}$ & $(0.51)$ \\
$p_{t}$ & $-0.16^{* * *}$ & $(0.06)$ \\
$g d p_{t}$ & $0.91^{* * *}$ & $(0.13)$ \\
$w_{t}$ & $1.96^{* * *}$ & $(0.43)$ \\
Adjusted $R^{2}$ & 0.99 & \\
\hline
\end{tabular}

Notes: $p_{t}$, is instrumented by its lag. Coefficient standard errors are given in parentheses. ${ }^{* * *}$ rejection of the null hypothesis at the $1 \%$ level.

The results imply a long-run price elasticity of demand of 16\%. McCarthy and Peach obtain an estimated long-run price elasticity of $24 \%$. $^{7}$ There are numerous of possible explanations for the higher long-run price elasticity of demand in the US compared to Switzerland. Generally speaking, laxer legal and institutional framework in the US may make a market more responsive to price changes. Relevant in this context are for example factors such as the accessibility to mortgages (e.g. due to a lower down-payment constraint) or the restrictiveness of the planning and regulatory environment. ${ }^{8}$

The estimated income elasticity of housing demand for Switzerland is slightly below 1 and not significantly different from McCarthy and Peach's estimate for

6 A Johansen Cointegration Test indicates that the residential stock, real housing prices, real GDP and real wages are cointegrated with one cointegrating vector. Tests for omitted variables indicate that variables such population, equity prices, consumption as proxy for permanent income of households and employee income do not belong in the equation and redundancy tests show that no variables can be left out. Recursive coefficient tests confirm that the coefficients are stable.

7 Grimes and Aitken (2006), whose dependent variable is the number of housing units per capita, find in their study for New Zealand a long-run price elasticity of 0.34 .

8 These findings are confirmed by Rosenthal, Duca and Gabriel (1991), who show with cross-sectional data that the price elasticity of demand falls markedly when one differentiates for households with strong credit constraints, and by Grimes and Aitken (2006), who find that price elasticity is lower in local authorities in which housing supply responsiveness is lower. 
the US. The wage variable enters the equation to control for labor market factors which are not covered by GDP and which have an independent effect on the stock of residential capital. Its significance in the equation implies that besides the size of overall income, proxied by GDP, households also incorporate the level of their basic wages in their long-run housing decisions, presuming that they stay in their present job.'

Although population is generally thought to be a key determinant of demand for housing stock, it turns out to be insignificant in our estimates for Switzerland. ${ }^{10}$ This indicates that it is not the size of the population that is relevant but how much that population is actually earning, which is captured by GDP.

The user cost of ownership, a variable which is frequently included in housing equations, is a function of interest payments, taxes, depreciation and house price appreciation. We have tested various user cost of capital formula, none of which prove to be significant in determining the long-run housing stock in Switzerland. This can be explained by the fact that in Switzerland the development of user costs is mainly driven by price developments, which are already included in the equation. ${ }^{11}$

As the long-run demand for housing is influenced by real housing prices, real GDP and real wages, which are all cyclical variables, it is not surprising that the estimated demand level fluctuates more than the very smooth housing stock, as shown in Figure 1. Generally speaking, the estimated demand rises above the actual supply at the end of boom periods, indicating excess demand, and falls below actual supply at the end of periods of reduced economic growth. This finding is consistent with theory and also in line with the empirical results of McCarthy and Peach for the US housing market.

Figure 1 shows that the housing market is rarely in equilibrium over a longer period of time. The forces behind the phases of excess supply and excess demand can be derived from the development of the macroeconomic variables described in equations (1) and (6).

9 The high coefficient could be assigned to the fact that real wages do not move linearly to the residential capital stock. This may be because components (such as the rise in working population) which are included in the capital stock and GDP are omitted in this variable. The coefficient might be overestimated due to this non-linearity.

10 We have tested the equation with various population age groups and their share of total population as well as with different lags. For further details, see Data appendix 6.6.

11 For detailed information, see Data appendix 6.7 
Figure 1: Residential Capital Stock and Estimates of the Long-Run Demand 1975-2007

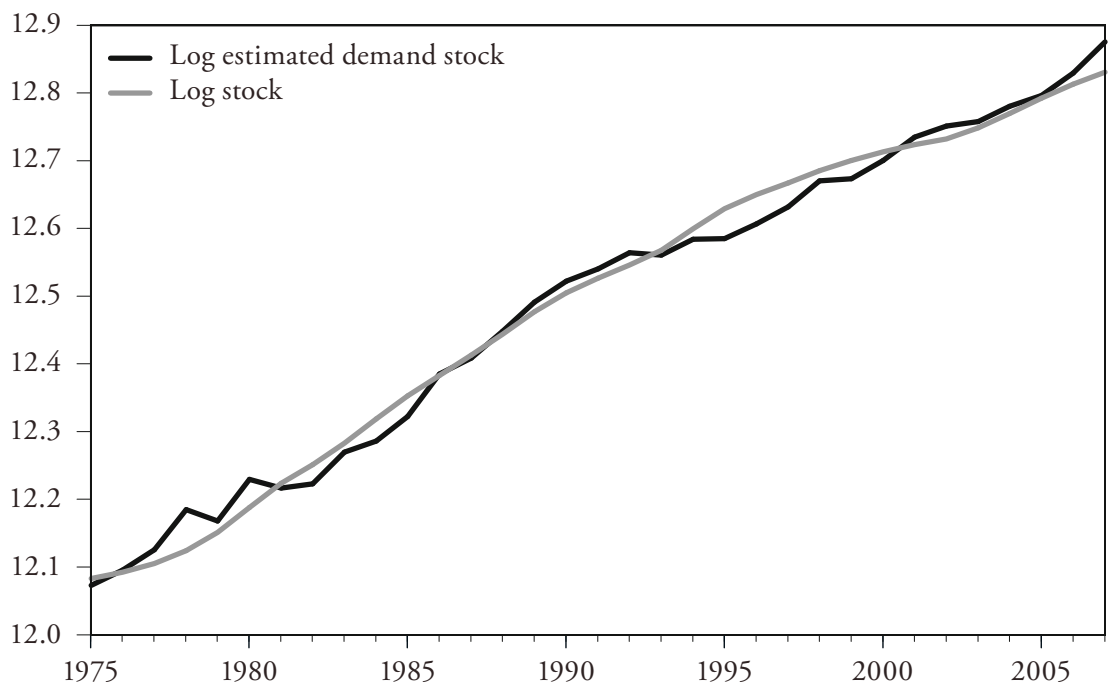

Source: Authors' computations.

In the second half of the seventies, a sharp rise in housing demand combined with a slow expansion of the housing stock led to a large amount of excess demand on the Swiss housing market. The situation reversed during the 1982 recession when demand contracted. The next economic upturn, which started in 1984, caused demand to increase again. However, the housing market remained in a state of excess supply for some years. This was because housing supply had expanded strongly at the beginning of the eighties due to a sharp drop in real interest rates, which had fueled residential investment. The strong rise in real housing prices in the second half of the eighties gave residential investment additional support and the housing stock increased at an annual rate above 3\% for seven years in a row. The Swiss economy slid into a sharp recession at the beginning of the nineties. However, in 1993-94, residential construction surged due to a governmental stimulus program designed to support the construction sector. A long period of excess supply thus followed. GDP and wages picked up in the second half of the nineties and a strong rise in housing demand finally brought the housing market back into balance in 2000. Robust growth in housing demand combined with moderate expansion of the stock resulted in a sharp rise in excess demand from 2006 onwards. 


\subsection{Price Adjustment}

The residuals of equation (6), $\varepsilon_{t}^{s}$, track the stock imbalance on the housing market. When demand rises above the existing supply of housing, prices are expected to rise, and vice-versa.This relationship is shown in Figure 2.

Figure 2: Change in Real Housing Prices and Estimates of Housing Market Imbalance 1976-2007

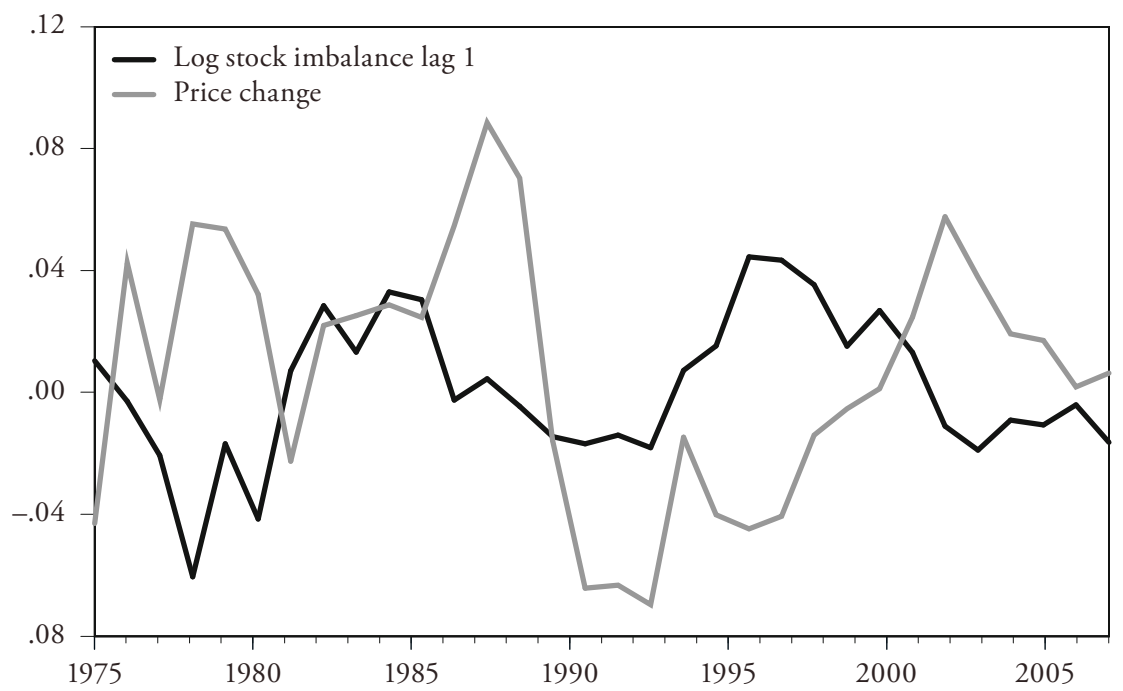

Sources: Authors' computations. Wüest \& Partner AG. Deflator: Swiss Federal Statistic Office.

As described in equation (3), besides $\varepsilon_{t}^{s}$, price adjustment is also influenced by other variables. In equation (7) changes in the nominal mortgage rate, $\Delta n_{t}$, are also included. Furthermore, to control for the period of overheating during the late eighties and the strong price correction thereafter, a dummy has been added, as suggested by Juselius (2006) ${ }^{12}$, with the value +1 in the years 1985-1989 and the value -1 in the years $1990-1994 .{ }^{13}$ For the rest of the sample the dummy has

12 See Juselius (2006), The Cointegrated VAR model, methodology and applications, p. 103.

13 Real housing prices in Switzerland increased at an average annual rate of 7.4\% during 1985 and 1989 and dropped sharply in the following years. 
the value 0 . Besides, an autoregressive term also enters the equation in order to capture persistence.

$$
\Delta p_{t}=\varphi_{1}+\varphi_{2} \varepsilon_{t-1}^{s}+\varphi_{3} \Delta n_{t}+\varphi_{4} \Delta p_{t-1}+\varphi_{5} d u m_{89}+\mu_{t}
$$

Parameter estimates are shown in Table 2. The coefficients have the expected sign and are statistically significant. According to the Breusch-Godfrey serial correlation LM Test, the null hypothesis that there is no serial correlation cannot be rejected. ${ }^{14}$

Table 2: OLS Parameter Estimates of Equation (7), 1976-2007

\begin{tabular}{lcl}
\hline Independent variable & \multicolumn{2}{c}{ Estimate } \\
\hline$C$ & 0.005 & $(0.004)$ \\
$\varepsilon_{t-1}^{s}$ & $-0.53^{* *}$ & $(0.20)$ \\
$\Delta n_{t}$ & $-1.52^{* *}$ & $(0.67)$ \\
$\Delta p_{t-1}$ & $0.29^{* *}$ & $(0.12)$ \\
dum $_{89}$ & $0.04^{* * *}$ & $(0.01)$ \\
Adjusted $R^{2}$ & 0.70 & \\
\hline
\end{tabular}

Notes: Coefficient standard errors are given in parentheses. **, ${ }^{* * *}$ rejection of the null hypothesis at the $5 \%$ and $1 \%$ level respectively.

The empirical results show that imbalances of the stock have a significant and large impact on prices. Furthermore, changes in nominal mortgage rates have a strong negative influence on short-run price developments.

14 Tests for omitted variables indicate that changes in GDP and population do not belong in the equation. This suggests that these demand-pushing variables are captured by $\varepsilon_{t}^{s}$. For changes in equity prices, the test rejects the nullhypothesis at a $10 \%$ significance level and the coefficient of this variable is very low and thus economically insignificant. The inclusion of the variable hardly affects the results. Redundancy tests indicate that no variables can be left out of the equation. Recursive coefficient tests show that the parameters are stable. 
The use of the nominal rates, as opposed to the real rates, is not only justified by its higher explanatory power but also by the fact that nominal interest rates are more closely related to financing constraints in the short run. ${ }^{15}$

\subsection{The Estimated Long-Run Level of Residential Investment}

Next we move to residential investment (equation (4)). Besides the logarithms of housing prices $^{16}$, the logarithms of the real construction deflator, $c c_{t}$, and real interest rates, $r_{t}$, also enter the investment equation, as cost-shifting variables.

$$
i_{t}=\beta_{1}+\beta_{2} p_{t}+\beta_{3} c c_{t}+\beta_{4} r_{t}+\varepsilon_{t}^{i}
$$

All coefficients have the expected sign and are statistically significant. According to the augmented Dickey-Fuller Unit Root Test, the null hypotheses of $\varepsilon_{t}^{i}$ having a unit root is rejected at the $1 \%$ level. ${ }^{17}$ The residuals of equation (8), i.e. the investment imbalance, are shown in Figure 4.

The empirical results of equation (8) indicate that in Switzerland housing prices have a strong positive influence on the long-run flow of new housing construction $^{18}$, while real mortgage rates and construction costs dampen investment, as expected.

Although mortgage rates already enter the price adjustment equation, the high sensitivity of housing investment to real mortgage rates indicates that they have

15 Borio and McGuire (2004) and VAN DEN Noord (2006) show that financing constraints, such as changes in the proportion of income absorbed by mortgage payments, are linked tightly to the level of the nominal mortgage rates, which therefore should be used for shortrun equations. Our estimates of housing price adjustment show that in Switzerland, too, the explanatory power of nominal interest rates is higher than that of the real rates.

16 In their two-sector Bayesian model Iacoviello and Neri (2010) attribute to housing prices the function of linking endogenously the demand for housing with residential investment. Their impulse response results show that a positive demand shock raises house prices and the returns from investing in the construction sector, thus causing residential investment to rise.

17 A Johansen Cointegration Test indicates that residential investment, real housing prices, real construction cost and real interest rates are cointegrated with one cointegrating vector. Tests for omitted variables indicate that variables such GDP, population and equity prices do not belong in the equation and redundancy tests show that no variables can be left out. Recursive coefficient tests confirm that the coefficients are stable.

18 The range of long-run price elasticity of supply in the literature is wide. While, for the US, Topel and Rosen (1988) and DiPasquale and Wheaton (1994) estimate price elasticities ranging from 1.2-2.2, McCarthy and Peach (2002) and Demers (2005) find much lower values around 0.4 . 
Table 3: Two-Stage Least Squares Parameter Estimates of Equation (8), 1975-2007

\begin{tabular}{lcc}
\hline Independent variable & \multicolumn{2}{c}{ Estimate } \\
\hline$C$ & $12.89^{* * *}$ & $(1.35)$ \\
$p_{t}$ & $1.35^{* * *}$ & $(0.18)$ \\
$c c_{t}$ & $-2.12^{* * *}$ & $(0.27)$ \\
$r_{t}$ & $-3.8^{* *}$ & $(1.53)$ \\
Adjusted $R^{2}$ & 0.78 & \\
\hline
\end{tabular}

Notes: $p_{t}$ is instrumented by its lag. Coefficient standard errors are given in parentheses. ${ }^{* *},{ }^{* * *}$ rejection of the null hypothesis at the $5 \%$ and $1 \%$ level respectively.

Figure 3: Residential Investment and Long-Run Estimates 1975-2007

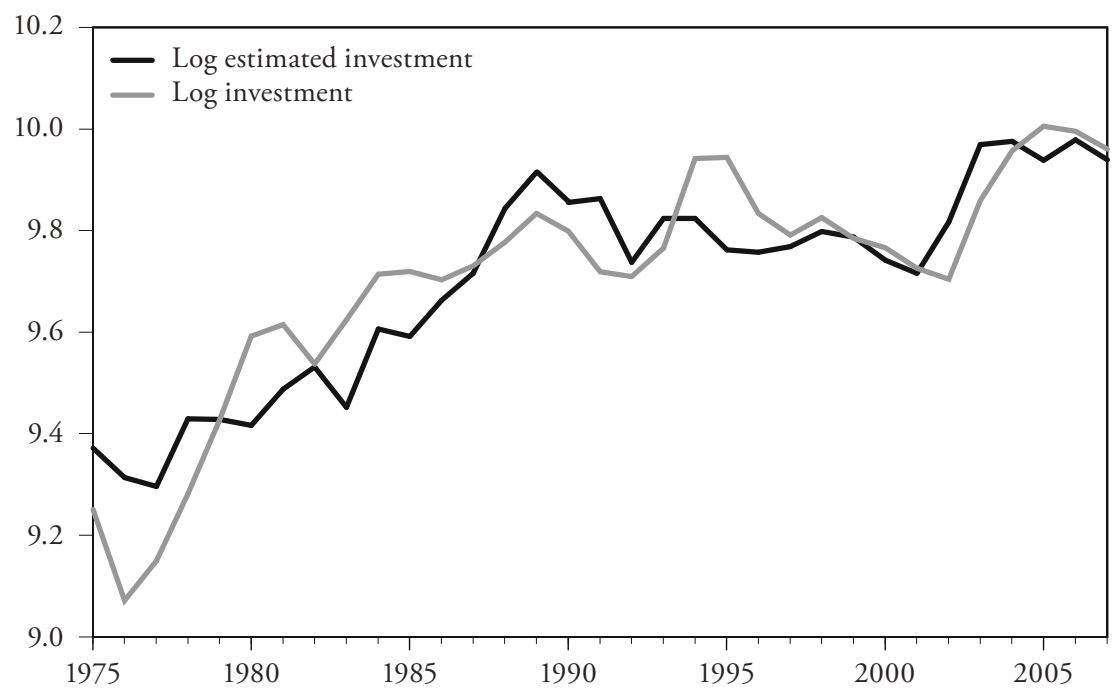

Sources: Authors' computations. Swiss Federal Statistic Office. 
an independent cost-shifting effect on residential investment. ${ }^{19}$ This is also consistent with the general view that monetary policy influences building investment through the interest rate transmission channel. ${ }^{20}$

Figure 3 depicts residential investment and the in-sample results of equation (8). It clearly shows that the quantity invested can diverge from its long-run equilibrium level in certain years. This may be due on one hand to the relatively long period elapsing between the decision to build and the actual construction start, owing to construction planning and lengthy administrative procedures (i.e. the procurement of a dwelling approval), or on the other hand to non-fundamental factors. For example, from beginning 1994 to mid-1995 a governmental housebuilding stimulation program was implemented and led to a sharp rise in investment which, according to equation (8), does not seem to be "fundamentally" justified. ${ }^{21}$

\subsection{Investment Dynamics}

In Figure 4 the dynamics of residential investment are depicted together with the lagged residuals of equation (8). Both series are negatively correlated with one another - indicating that over- or under-investment will be corrected (at least partially) in the following period.

Besides $\varepsilon_{t}^{i}$, changes in mortgage rates also influence the investment adjustment process. As in the price adjustment equation, mortgage rates are denoted in nominal terms, $n_{t}$. Given that a housing unit in Switzerland takes over a year to be constructed, many projects that have been started in the course of a year are likely still to be under construction during the following year. It therefore makes sense to include a lag in the growth in investment.

$$
\Delta i_{t}=\gamma_{1}+\gamma_{2} \varepsilon_{t-1}^{i}+\gamma_{3} \Delta n_{t-1}+\gamma_{4} \Delta i_{t-1}+\zeta_{t}
$$

19 This topic is thoroughly discussed by Topel and Rosen (1988) who justify the inclusion of mortgage rates in their supply equation by using them as an additional cost shifter reflecting the cost of capital for builders (as opposed to a demand shifter). McCarthy and Peach (2002) as well as DiPasquale and Wheaton (1992) include not only housing prices but also land prices and T-bill rates in their long-run supply equations.

20 Iacoviello and Neri (2010) demonstrate in their two-sector Bayesian model that of all components of aggregate demand, residential investment reacts the strongest to a monetary policy shock.

21 In 1994, in the midst of a severe economic recession, residential construction increased by $17.7 \%$. This was the highest annual rise in residential construction since 1971. For more details, see SAurer (1996). 
Figure 4: Change in Real Investment and Estimated Imbalances 1976-2007

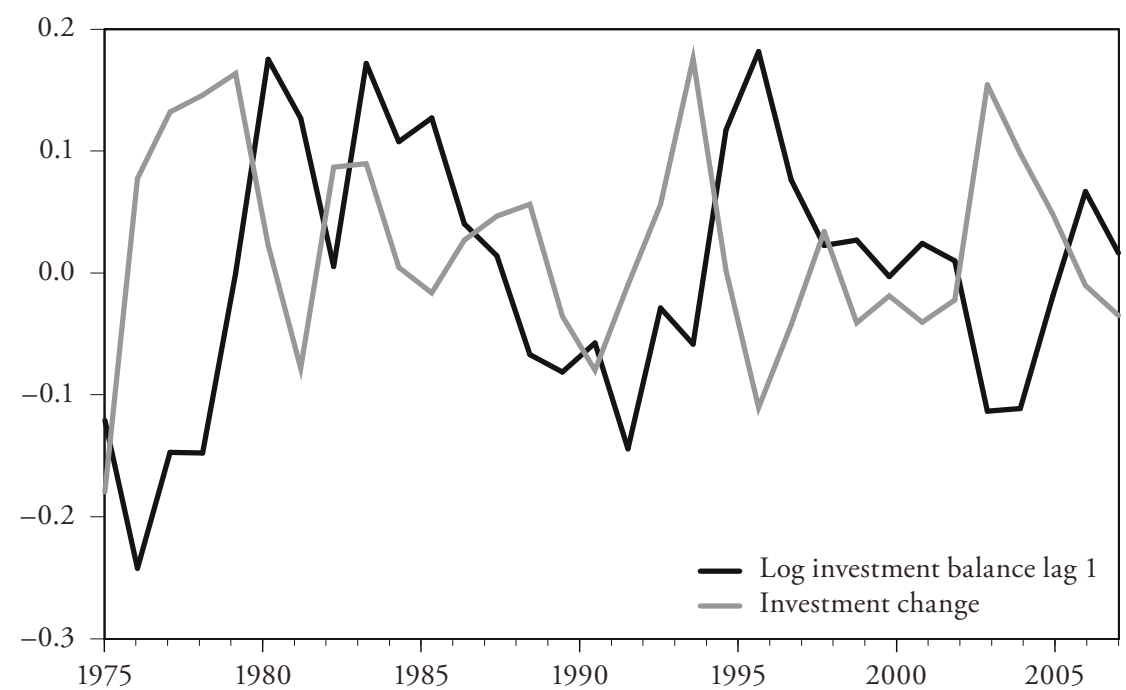

Sources: Authors' computations. Swiss Federal Statistic Office.

Parameter estimates are shown in Table 4. The coefficients have the expected sign and are statistically significant. According to the Breusch-Godfrey serial correlation LM Test, the null hypothesis that there is no serial correlation cannot be rejected. ${ }^{22}$

The results indicate that only about one third of the imbalances in long-run investment will be corrected in the following year. This relatively sluggish adjustment process could be explained by the relatively long period elapsing before construction can even be started: Peters and Wapf (2007) estimate that the time needed to procure a dwelling approval takes on average about 6 months in Switzerland.

22 Tests for omitted variables indicate that changes in GDP equity prices and population do not additionally belong in the equation. Redundancy tests indicate that no variables can be left out of the equation. Recursive coefficient tests show that the parameters are stable. 
Table 4: OLS Parameter Estimates of Equation (9), 1976-2007

\begin{tabular}{lcl}
\hline Independent variable & \multicolumn{2}{c}{ Estimate } \\
\hline$C$ & 0.001 & $(0.001)$ \\
$\varepsilon_{t-1}^{s}$ & $-0.33^{* * *}$ & $(0.09)$ \\
$\Delta n_{t}$ & $-6.21^{* * *}$ & $(1.56)$ \\
$\Delta i_{t-1}$ & $0.40^{* * *}$ & $(0.10)$ \\
Adjusted $R^{2}$ & 0.63 & \\
\hline
\end{tabular}

Notes: Coefficient standard errors are given in parentheses.

*** rejection of the null hypothesis at the $1 \%$ level.

\section{Conclusion}

This paper analyzes the determinants of the residential capital stock, residential investment and housing prices in Switzerland in a stock-flow framework. A disequilibrium approach was applied, allowing prices and investment to adjust to shocks in several periods.

A long-run demand-level residential capital stock is estimated using real housing prices, real GDP and real wages. Empirical results indicate that the desired level of residential capital stock can diverge from the existing residential capital stock for several years. This is not surprising given the fact that the flow of net residential investment only accounts for about $2 \%$ of the stock and that consequently the housing stock cannot adjust rapidly to shocks. Imbalances therefore have to be cleared in the short run by price adjustments, and indeed, changes in prices are significantly and strongly dependent on the level of residential stock imbalances.

Housing prices, which are determined by the level of the housing stock, are important in explaining the evolution of residential investment - together with the two cost-shifting variables construction costs and the mortgage rate. Results show that one third of the divergences of actual investment from the estimated long-run level will be corrected in the following year. This is a reasonable result, given the slow planning process in residential construction in Switzerland.

The empirical results of the model are in line with theory although the figures used are highly aggregated. Over the past years, some regions in Switzerland (cities and their agglomerations) have become continually more attractive, while others have lost economic importance. Strong migration flows from less attractive regions in Switzerland and from foreign countries towards the cities have 
had an important impact on the regional housing markets. Additional regional analysis could help us to understand these features better and it would be interesting to see if the development of regional markets confirms our findings of the aggregated market. This, however, is left for future research.

\section{Data Appendix}

\subsection{Data Sources}

Table 5: Data Sources

\begin{tabular}{|c|c|c|}
\hline & Variable & Source \\
\hline \multirow[t]{2}{*}{$g d p_{t}$} & Real GDP & FSO: National Accounts \\
\hline & GDP Deflator & FSO: National Accounts \\
\hline$i_{t}$ & Real residential investment & $\begin{array}{l}\text { FSO: 1948-1990 National Accounts for structures } \\
\text { and equipment, 1990-2007 National Accounts }\end{array}$ \\
\hline$c c_{t}$ & Real construction deflator & $\begin{array}{l}\text { FSO: 1948-1990 National Accounts for structures and } \\
\text { equipment. 1990-2007 National Accounts. The FSO } \\
\text { calculates the construction deflator with the semi- } \\
\text { annual construction costs index. Deflation with the } \\
\text { GDP deflator }\end{array}$ \\
\hline$w_{t}$ & Real wages & FSO: Swiss real wage index, total \\
\hline$n_{t}$ & Nominal mortgage rates & $\begin{array}{l}\text { SNB: Interest rates on new first mortgages, average } \\
\text { of cantonal banks' published rates }\end{array}$ \\
\hline$r_{t}$ & Real mortgage rates & $\begin{array}{l}\text { SNB and FSO: The nominal mortgage rates have } \\
\text { been deflated with the GDP deflator }\end{array}$ \\
\hline$p_{t}$ & Housing prices & $\begin{array}{l}\text { Wüest \& Partner AG: Weighted average of the supply } \\
\text { price indexes for single-family houses and condo- } \\
\text { miniums. The weights have been provided by Wüest } \\
\text { \& Partner AG. Deflation with the GDP deflator }\end{array}$ \\
\hline
\end{tabular}

FSO: Swiss Federal Statistic Office; SNB: Swiss National Bank.

\section{2 The Residential Capital Stock}

As described in equation (1), the residential capital stock in any period is determined by the existing stock in the previous period, the rate of depreciation of the existing stock and the flow of new residential construction investment. The residential capital stock used in this paper is calculated with the perpetual 
inventory method and a geometric pattern of decay as proposed by the FSO. ${ }^{23}$ The geometric model implies that the stock depreciates at a constant rate. Equation (10) shows a detailed version of the capital accumulation identity. $S_{0}$ is the starting value of the stock in $1948^{24}$ and $d$ is the depreciation rate, assumed to be constant at $4 \%$ p.a. ${ }^{25}$

$$
S_{t}=(1-d)^{t} S_{0}+\sum_{\beta=0}^{t-1}(1-d)^{\beta} I_{t-\beta}
$$

All volume data are rebased at 2000 prices. The building deflator was used for this purpose. Thus, the residential capital stock measures the price one would have had to pay in 2000 to rebuild the entire stock of any specific year, taking into account thevintage (i.e. the age) of the housing units. Figure 5 plots the real residential capital stock, which in 2007 was worth over CHF 370 billion - approximately three quarters of annual real GDP. Over the period 1975-2007, the real housing stock more than doubled, growing relatively smoothly (on average $2.4 \%$ p.a.).

\subsection{Gross and Net Residential Investment}

Figure 6 plots the annual level of gross residential investment (real residential construction) and net residential investment (real residential construction minus depreciation).

While gross residential investment has doubled since 1975, net residential investment has only risen modestly since the beginning of the sample. This shows that the upward trend of investment in residential construction is mainly due to rising depreciation, which increases proportionally to the stock.

In Figure 7, the ratio of net investment to stock is shown. In Switzerland, the net residential investment amounts for $1.0 \%$ to $3.5 \%$ (on average over the whole sample: $2.3 \%$ ) of the housing stock, and seems to be decreasing over time. This low ratio makes quick variations in the level of the residential capital stock practically impossible.

23 See Rais and Sollberger, FSO, 2009.

24 The starting value of the stock in 1948 is taken from work done by GoldSMith (1980). The nominal term has been rebased to 2000 prices. Note however that the initial level of the stock has little impact on the level of the stock in 1975 (the starting date of our model). This is because of the strong net residential investment in the first two decades.

25 The depreciation rate of $4 \%$ p.a. is derived from the expected life span of 50 years as proposed by Rais and Sollberger, FSO, 2009. 
Figure 5: Residential Capital Stock, in 2000 Prices, 1975-2007

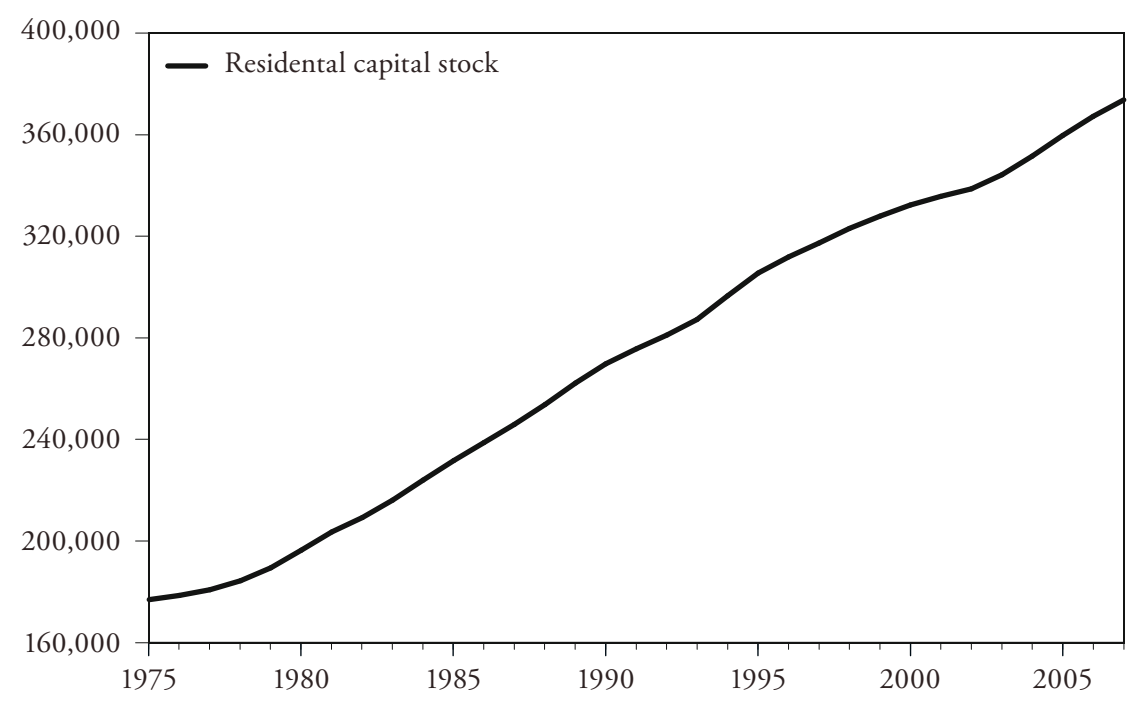

Source: Authors' computations.

Figure 6: Residential Investment, Gross and Net, in 2000 Prices, 1975-2007

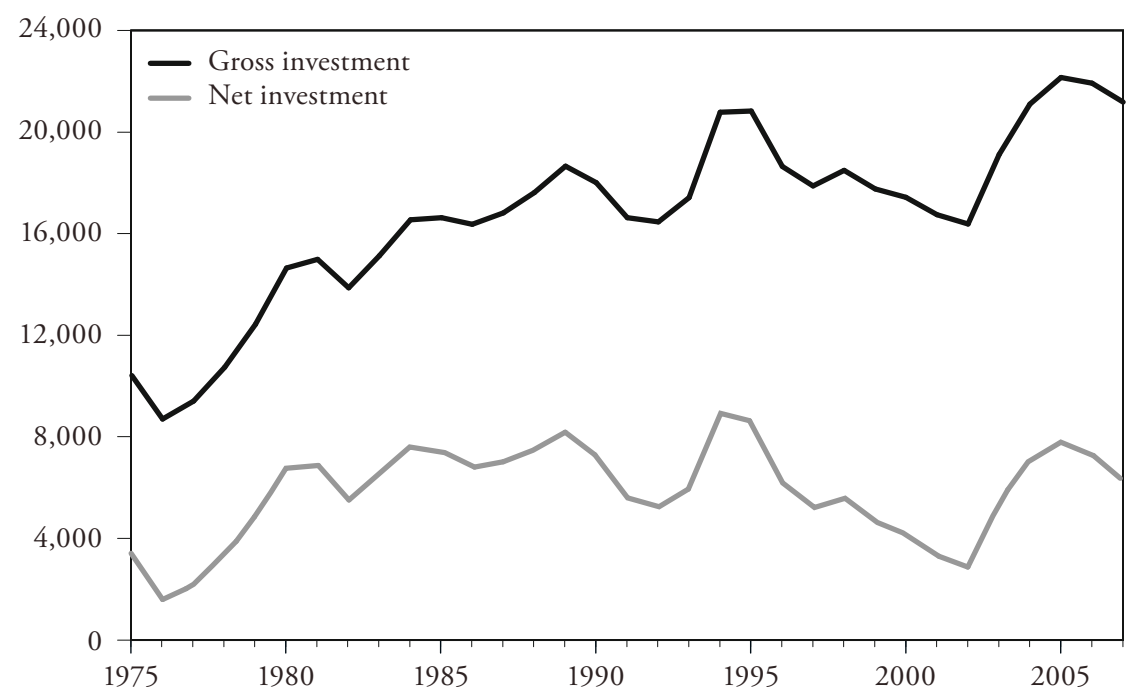

Sources: Swiss Federal Statistic Office. Authors' computations. 


\subsection{Housing Prices}

The housing prices used in this paper are supply sale prices, i.e. neither rental prices nor hedonic prices.

Sale versus rental prices: Sale prices are the sum of the discounted expected future rental yield. It is therefore correct to use sale prices as the price measure which is set to clear the housing market even though about $65 \%$ of all households in Switzerland rent their home. In Figure 8 the real supply sale prices are plotted together with real supply rents. Both series are provided by Wüest $\&$ Partner AG and are deflated with the GDP deflator. Rents tend to have a lag on sale prices and reacted much stronger to the tightness on the housing market in the nineties. Nonetheless, the start and end points of both series are more or less the same.

Supply versus hedonic prices: While supply price indices represent the median asking price for housing units, hedonic prices price indices measure the price paid for a housing unit of a given quality, i.e. controlling for differences in characteristics such as number of rooms, size of plot, age, distance to the city center, etc. Hedonic indices, therefore, provide information on the rise/ decrease of prices independently of the change in quality of the sold housing units. Hedonic indices should be used in models which quantify the supply of housing by number of housing units. In models in which the housing supply is expressed in real CHF (or any other currency) and which therefore include changes in quality it is correct to use prices which are not quality-adjusted, i.e supply price indexes. In Figure 9 the supply sale price index of Wüest \& Partner AG is plotted together with the hedonic price indices of Wüest \& Partner $A G$ and IAZI AG ${ }^{26}$. All series are deflated with the GDP deflator.

\subsection{Labor Market Measures and GDP}

A labor market variable is often included in housing demand equations. Figure 10 shows the development of GDP and the number of employees and the number of hours worked in Switzerland. Due to productivity gains, employment has grown at a slower speed than GDP. However, the overall pattern is quite similar. Using Swiss data, the introduction of either of these employment variables in the equation would be problematic because of the risk of multicollinearity.

26 SWX IAZI Private Real Estate Price Index, covering single-family houses and condominiums. 
Figure 7: Ratio of Net Investment to Stock, 1975-2007

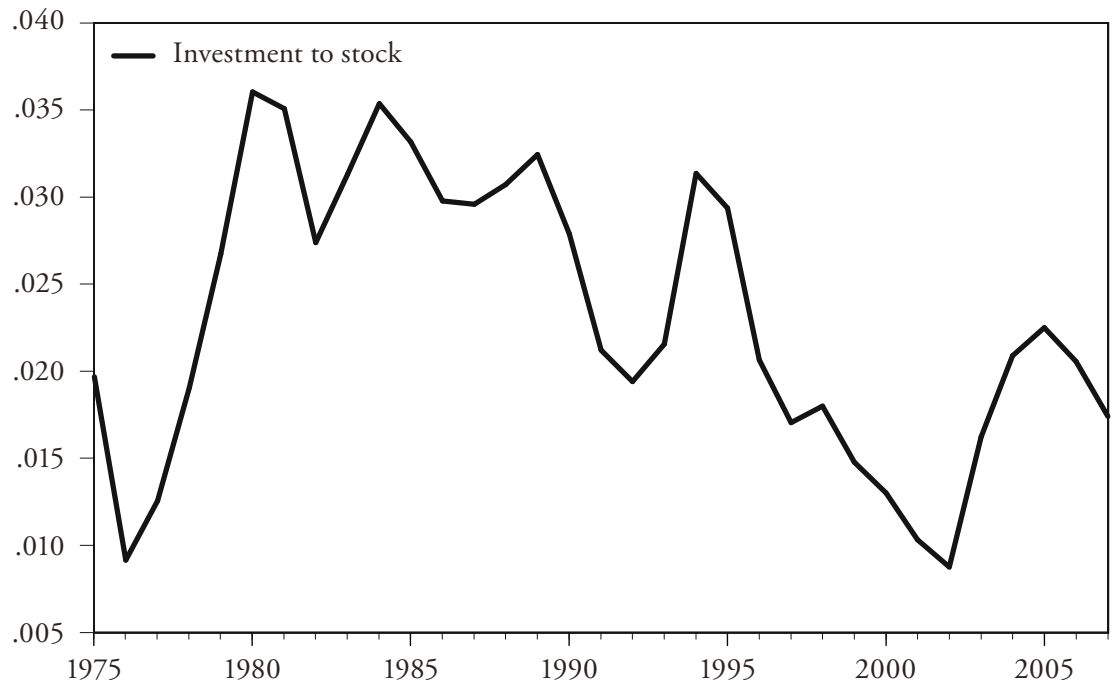

Source: Authors' computations.

Figure 8: Real Supply Prices, Sale vs Rent,

Indexed at 100 in 1986, 1975-2007

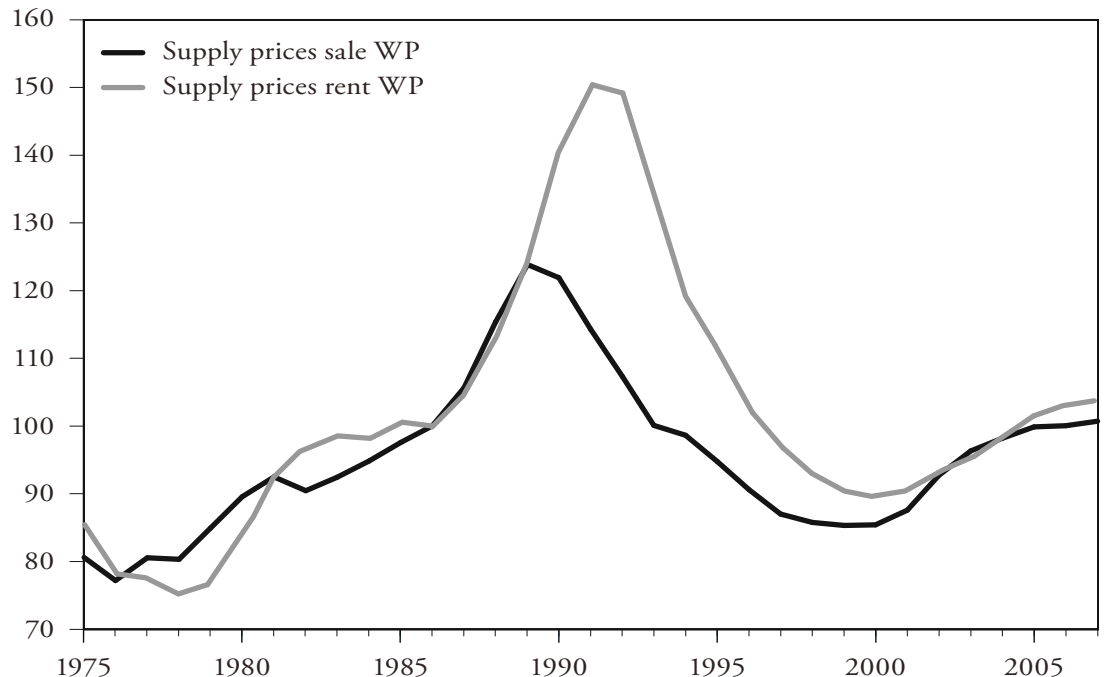

Sources: Wüest \& Partner AG. Deflator: Swiss Federal Statistic Office. 
Figure 9. Real Sale Prices, Supply vs Hedonic, Indexed at 100 in 1986, 1975-2007

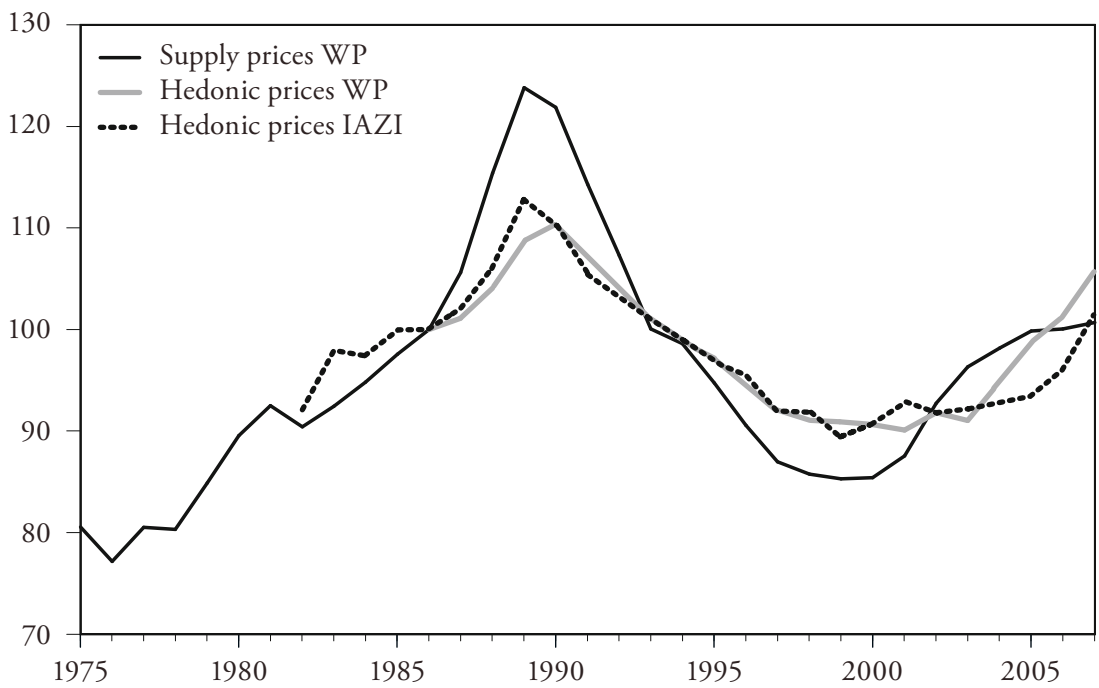

Sources: Wüest \& Partner AG. IAZI AG. Deflator: Swiss Federal Statistic Office.

Figure 10: Real GDP and Employment, Indexed at 100 in 1975, 1975-2007

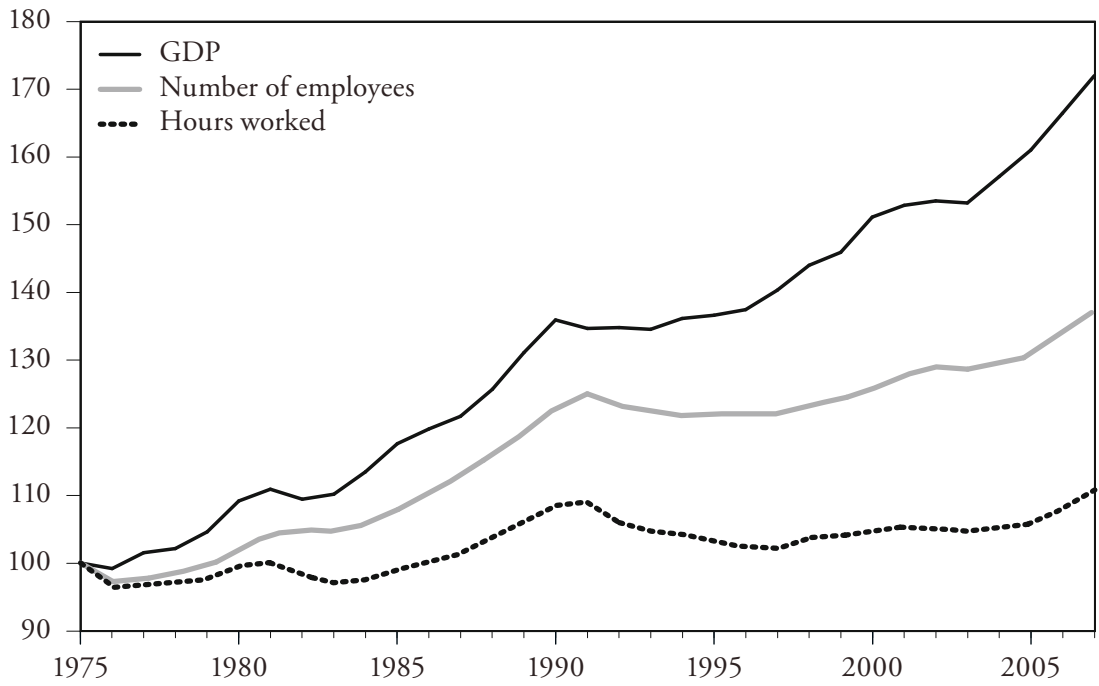

Source: Swiss Federal Statistic Office. 
Figure 11: Real GDP and FSO Real Wages, Indexed at 100 in 1975, 1975-2007

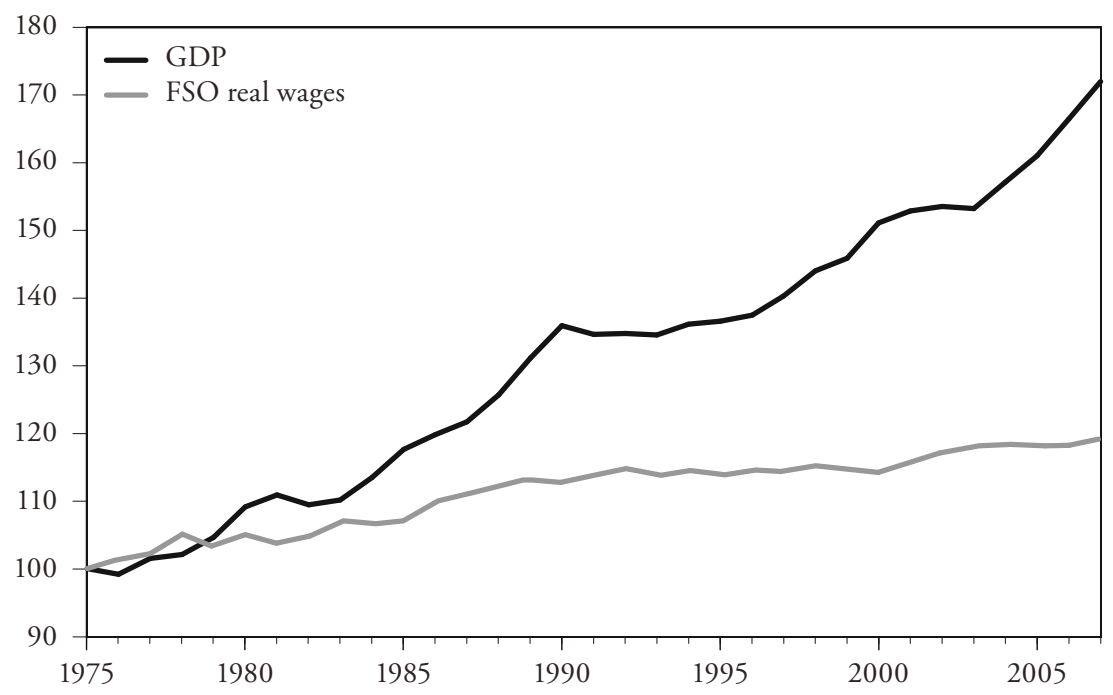

Source: Swiss Federal Statistic Office.

In Figure 11, GDP is plotted together with the FSO real wage index. This wage index does not measure wage developments due to changes in qualification nor does it include any bonus payments, but measures the development in basic wages given an unchanged employment structure. In other words, this index measures the income of an average employee who stays at the same job over time. Figure 9 shows that the information incorporated in the FSO wage index is quite different than that in GDP.

\subsection{Population}

The assumption that population should be a key determinant of housing demand is quite quite straightforward given that housing is a necessity. Implicitly it is assumed that if population increases, the number of housing units and therefore also the housing stock should increase. However, in our long-run housing stock equation (equation (6)) population turns out to be insignificant even though different lags and various age groups were tested. Figure 12 gives some explanation for these results. 
Figure 12. Residential Capital Stock, Number of Housing Units and Population, Indexed at 100 in 1975, 1975-2007

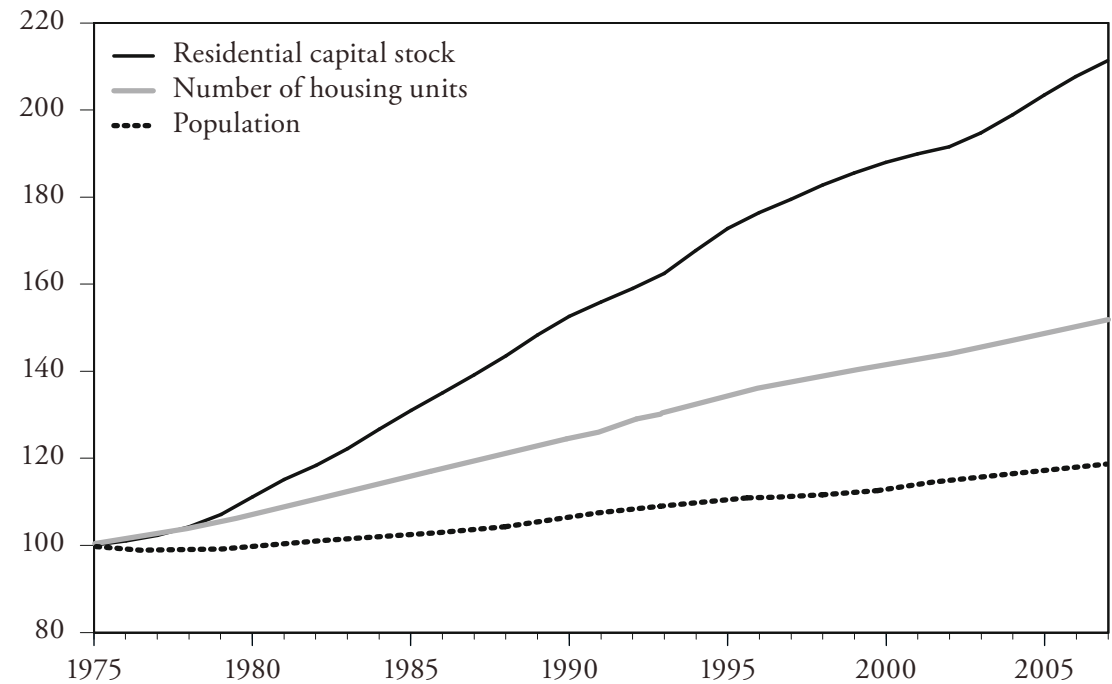

Sources: Swiss Federal Statistic Office. Authors' computations.

Firstly, over the past three decades, the number of housing units has risen 2.6 times quicker than population, indicating that beside population other factors influence the number of housing units, such as changes in the social structure of the Swiss population or increasing income. Secondly, the residential housing stock has risen more than twice as fast as the number of housing units. This means that the size and quality of the new dwellings has increased considerably, which can probably be explained by higher income. In our view this indicates that it is not the size of the population that is relevant but how much that population is earning, which is captured in equation (6) by GDP. ${ }^{27}$

27 The fact that housing market variables are sensitive to population in some models but not in ours may be explained by the specifications of these models and by the data sample. 


\subsection{User Costs of Capital}

The user cost of capital is typically calculated as a function of interest rates and house price appreciation. Several user cost of capital formula exisit. Ignoring taxes and including the depreciation rate, a broad definition could be:

$$
U_{t}=P_{t-1}\left(n_{t}+\delta-\pi_{t}\right)
$$

where $P_{\mathrm{t}-1}$ is the real housing price of the previous period, $n_{t}$ is the nominal mortgage rate, $\delta$ is the rate of depreciation (which we assume to be constant at $4 \%$ ) and $\pi_{t}$ is the nominal annual housing price inflation. A constant was added to the series to ensure that there were no negative values of user costs.

In Figure 13, the change in housing prices is plotted together with the user costs of capital. This chart shows that in Switzerland the user cost of capital is mainly determined by the inverse change in housing prices. Using Swiss data, it would therefore be problematic to explain the change in housing prices with the user costs of capital.

Figure 13: Change in Real Housing Prices and User Costs of Capital (rhs), 1975-2007

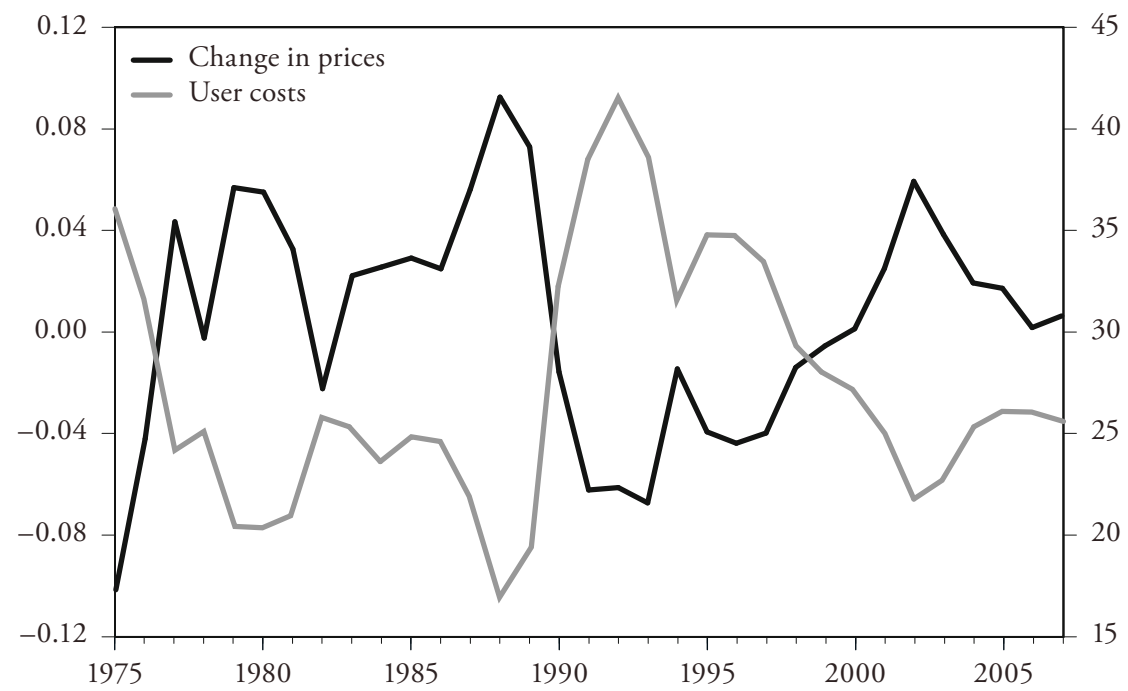

Sources: Wüest \& Partner AG. Deflator: Swiss Federal Statistic Office. Authors' computations. 


\section{References}

Borio, Claudio, and Patrick McGuire (2004), “Twin Peaks in Equity and Housing Prices?”, BIS Quarterly Review, 7, pp. 79-96.

Borowiecki, Karol Jan (2009), "The Determinants of House Prices and Construction: An Empirical Investigation of the Swiss Housing Economy", International Real Estate Review, 12 (3), pp. 193-220.

Bourassa, Steven, Martin Hoesli and Donato Scognamiglio (2009), "Housing Finance, Prices, and Tenure in Switzerland", Research Paper 16, Swiss Finance Institute.

Demers, Frederick (2005), "Modelling and Forecasting Housing Investment: The Case of Canada", Working Paper 2005-41, Bank of Canada.

DiPasquale, Denise, and William C. Wheaton (1994), "Housing Market Dynamics and the Future of Housing Prices", Journal of Urban Economics, 35, pp. 1-27.

Goldsmith, Raymond W. (1981), "A Tentative Secular National Balance Sheet for Switzerland", Swiss Journal of Economics and Statistics, 117 (2), pp. 175-187.

Grimes, Arthur, and Andrew Aitken (2006), "Housing Supply and Price Adjustment", Working Paper MWP0601, Motu Economic and Public Policy Research.

Нотt, Christian (2009), "Explaining House Price Fluctuations", Working Paper 2009-5, Swiss National Bank.

Iacoviello, Matteo, and Stefano Neri (2010), "Housing Market Spillovers:

Evidence from an Estimated DSGE Model”, American Economic Journal: Macroeconomics, forthcoming.

Juselius, Katarina (2006), The Cointegrated VAR Model, Methodology and Applications, New York: Oxford University Press Inc.

McCarthy, Jonathan, and Richard W. Peach (2002), "Monetary Policy Transmission to Residential Investment", FRBNY Economic Policy Review, 8 (1).

Peters, Matthias, and Bettina Wapf (2007), „Befragung von Schweizer Baugesuchstellern“, Die Volkswirtschaft, 80 (5).

Rais, Gregory, and Pierre Sollberger (2009), „Nichtfinanzieller Kapitalstock, Methodenbericht", Working paper, Bundesamt für Statistik BFS.

Riddel, Mary (2004), "Housing-Market Disequilibrium: An Examination of Housing-Market Price and Stock Dynamics 1967-1998”, Journal of Housing Economics, 13 (2), pp. 120-135. 
Rosenthal, Stuart S., John V. Duca and Stuart A. Gabriel (1991), "Credit Rationing and the Demand for Owner-occupied Housing", Journal of Urban Economics, 30 (1), pp. 48-63.

Rudolf, Barbara, and Mathias Zurlinden (2009), "Measuring Capital Stocks and Capital Services in Switzerland", Swiss Journal of Economics and Statistics, 145 (1), pp. 61-105.

Saurer, Peter (1996), „Der Investitionsbonus 1993-1995, Schlussbericht“, Mitteilungsblatt für Konjunkturfragen, 52 (3), pp.3-16.

Topel, Robert, and Sherwin Rosen (1988), "Housing Investment in the United States", The Journal of Political Economy, 96 (4), pp.718-740.

van den Noord, Paul J. (2006), "Are House Prices Nearing a Peak? A Probit Analysis for 17 OECD Countries", Working Paper 488, OECD Economics Department.

\section{SUMMARY}

This paper analyzes the development of housing market imbalances, housing prices and residential investment in Switzerland within a stock-flow framework. In the long run, the desired level of residential capital stock and the existing residential capital stock revert. Empirical results indicate, however, that housing demand can diverge from the existing supply for several years due to the slow adjustment of the residential capital stock to shocks. In the short run, the market therefore has to be cleared by price adjustments. And indeed, it can be shown empirically that changes in prices are significantly and strongly dependent on the level of stock imbalances. Furthermore, housing prices prove to be an important determinant of residential investment, which in turn drives the adjustment process of the residential capital stock towards its desired level. 